\title{
Chemical study of the seeds of Ximenia americana: analysis of methyl esters by gas chromatography coupled to mass spectrometry
}

\begin{abstract}
Fresh seeds of Ximenia americana presented high levels of protein (19.77\%) and oil $(27.71 \%)$. The oil components of the seeds, obtained by extraction with hexane, were subjected to the saponification/methylation reactions to produce methyl esters. The esters were then analyzed by gas chromatography-mass spectrometry allowing the identification of ten fatty acids. The main ones were oleic (55\%), ximeninic (17\%) and cis-19-octacosenóico $(10 \%)$. The analysis process involved the fragmentation pattern exhibited by the methyl derivayives in their respective mass spectra.
\end{abstract}

Keywords: Ximenia Americana, Olacaceae, fatty acids; ximeninic acid; GC/MS
Volume 7 Issue I - 2018

\author{
Romézio Alves Carvalho da Silva,Telma Leda \\ Gomes de Lemos, Daniele Alves Ferreira, \\ Francisco Jos Queiroz Monte \\ Department of Organic and Inorganic Chemistry - Science \\ Center, Federal University of Ceará, Brazil
}

\begin{abstract}
Correspondence: Romézio Alves Carvalho da Silva, Postgraduate Program in Chemistry, Department of Organic and Inorganic Chemistry - Science Center, Federal University of Ceará, Brazil, Email fmonte@dqoi.ufc.brs
\end{abstract}

Received: January 25, 2018 | Published: February 12, 2018

\section{Introduction}

Beans are esterified natural fats have a prominent role in human nutrition, playing important biological functions for metabolism. Bones of the earth and the walls of the walls of the walls of the walls of the walls of the walls of the walls and the walls of the walls of the walls of the walls of the building blocks of the floor and the walls of the floor, resultando em proteção cardiovascular. ${ }^{1}$ You may know that you are getting enough of these products to be used in the manufacture of sabers and detergents, or acidic products, for example, which are food-based. Although unsaturated fatty acids are the healthiest, studies are still needed to improve the conservation of edible oils, especially in oils with a high concentration of unsaturated as a result of autooxidation (rancidity). ${ }^{2}$ It is worth adding the use of natural fatty acids for the production of biofuels by esterification with light alcohols (methanol, ethanol).Considering the main objective of the study, that is, the identification of $X$. americana seed oil components by gas chromatography coupled to mass spectrometry (CG / MS) and also for the purpose of comparison with the analysis made from derived by silylation, ${ }^{3}$ components of the oil were converted to esters of fatty acids by means of methylation reaction. Basically, two reactional pathways have been most frequently used to convert fatty acids to methyl esters: mild alkaline methanolysis and saponification followed by fatty acid methylation (saponification/methylation). The mild alkaline methanolysis is a single-stage transesterification reaction catalyzed by an alkali in the presence of methanol, which is mainly effective for the formation of fatty acid methyl esters from esterlinked lipids. ${ }^{4}$ The pathway via saponification/methylation is efficient to produce fatty acid methyl esters (and other methylated compounds) from fatty acids and free aldehydes, as well as from ester, ether and amine lipids. The process is carried out in two steps, both at elevated temperature, which includes base catalyzed saponification (usually $\mathrm{NaOH}$ or $\mathrm{KOH}$ ) and acid catalyzed methylation $\left(\mathrm{HCl}\right.$ or $\left.\mathrm{H}_{2} \mathrm{SO}_{4}\right)$ in the presence of methanol. In the first step alkali metal (saponification) long chain salts are formed, which, in a second step, are converted into volatile forms (methyl esters) for analysis by gas chromatography coupled to mass spectrometry (GC/MS).

Considering the already known biological activities of the bark, stem and roots of $X$. american $a^{5}$ and considering its abundance in the Brazilian Northeast, the present study aimed to contribute with the chemical knowledge of the species regarding the seeds of its edible fruits. Seeds with a high lipid mass, high levels of total protein $(19.77 \%)$ and oil $(27.71 \%)$ could eventually take advantage of nutraceutical (human or animal), medicinal, cosmetic, ${ }^{6-8}$ or as raw material for the production of biodiesel.

\section{Experimental}

\section{General methods}

Gas chromatography coupled to mass spectrometry (GC/MS) analyzes were performed on Shimadzu GC-2010 apparatus coupled to a GCMS-QP2010SE mass spectrometer equipped with Rtx ${ }^{\circledR}-5 \mathrm{MS}$ (95\% dimethylpolysiloxane and $5 \%$ diphenyl) column of $30 \mathrm{~m}, 0.25$ $\mathrm{mm}$ internal diameter and $0.25 \mu \mathrm{m}$ film thickness of the fixed phase. Conditions: $80^{\circ} \mathrm{C}(3 \mathrm{~min})$ to $280^{\circ} \mathrm{C}(5 \mathrm{~min})$ at $5^{\circ} \mathrm{C} / \mathrm{min}$, then $20^{\circ} \mathrm{C} /$ min to $300^{\circ} \mathrm{C}(5 \mathrm{~min})$ using $\mathrm{He}$ as drag gas at a flow rate of $1.7 \mathrm{~mL}$ $/ \mathrm{min}$; injector temperature of $250^{\circ} \mathrm{C}$ and detector of $300^{\circ} \mathrm{C}$. The analysis with the mass detector was in the scan mode with analysis time in $40 \mathrm{~min}$; the recording of the mass spectra was in the range of 35 to 500 Daltons by impact of electrons with ionization energy of $70 \mathrm{eV}$ (voltage of 1,5 KV), quadrupole type analyzer and source of ions at $240^{\circ} \mathrm{C}$; cc were performed using Merck H60 gel, and tlc with Si gel Merck $60 \mathrm{~F}_{254}$. Total protein content (\%) in the grains of $X$. americana. The initial experiment consisted in determining the total protein content in the enzymatic system used, that is, the internal part of the grains of $X$. americana. Using the methodology of Nogueira and Souza, ${ }^{9}$ a considerable content of $19.77 \%$ was found.

\section{Moisture content (\%) in grains of $X$. americana}

The grains $(30.974 \mathrm{~g})$ were oven-dried at a temperature of $105^{\circ} \mathrm{C}$ for $24 \mathrm{~h}$, time required to obtain a constant mass $(21.394 \mathrm{~g})$. The moisture content was obtained according to the equation below, with a value of $31.32 \%$

$$
\text { Moisture }(\%)=\frac{m i-m f}{m i} \mathrm{X} 100
$$




$$
\begin{aligned}
& \text { At where: } \\
& \mathrm{mi}=\text { initial seed mass. } \\
& \mathrm{mf}=\text { final seed mass. }
\end{aligned}
$$

\section{Oil content in (\%) in grains of $X$. americana}

The oil content was determined from the internal part of the grains (dehydrated matter $=21.394 \mathrm{~g}$ ) using a Soxhlet type extractor and hexane as solvent in a continuous and uninterrupted extraction process for 6:00 h. After this time, the solvent was evaporated under reduced pressure to give a mass of fixed oil $(5.90 \mathrm{~g})$, which represented $27.71 \%$ oil in the beans.

\section{Obtaining extracts}

Fresh seeds after drying at room temperature for one week were reduced in small granules. A sample $(424.0 \mathrm{~g})$ was extracted with hexane $(1: 3 \mathrm{~m} / \mathrm{v})$ at room temperature four consecutive times, each extraction lasting for three days. The solutions were filtered, pooled and the hexane removed in vacuo yielding the hexane extract as yellow dense oil (EHXA, 148.0g). Part (20.3g) of this oil was subjected to a silica gel filter column eluted successively with hexane, dichloromethane and ethyl acetate. The solvents were evaporated under reduced pressure giving the FHEHXA (11.45g), FDEHXA $(2.17 \mathrm{~g})$ and FAEHXA (1.56 g) fractions respectively.

\section{Obtaining the methyl esters}

Saponification: To one part (10.0 g) of the hexane fraction (FHEHXA) in $\mathrm{MeOH}(80 \mathrm{~mL})$ was added $\mathrm{KOH}(10.0 \mathrm{~g})$ and the mixture was kept under reflux for $1 \mathrm{~h}$. After cooling, distilled H 2 O $(240 \mathrm{~mL})$ was added and the alkaline hydroalcohol solution was extracted with hexane $(3 \times 50 \mathrm{~mL})$ in decantation funnel. The organic phases were combined, dried over $\mathrm{Na}_{2} \mathrm{SO}_{4}$ and concentrated under reduced pressure, the unsaponifiables giving the pale yellow solid $(1.87 \mathrm{~g})$. The hydroalcoholic phase was acidified with $20 \% \mathrm{HCl}$ to $\mathrm{pH} 3-4$ and then subjected to extraction with AcOEt $(3 \times 50 \mathrm{~mL})$. The organic phases were combined, dried over $\mathrm{Na}_{2} \mathrm{SO}_{4}$ and concentrated under reduced pressure to give the saponifiables as a bleached solid $(7.15 \mathrm{~g})$.

Methylation: To one part ( $2.0 \mathrm{~g}$ ) of the saponifiable material in $\mathrm{MeOH}$ $(20.0 \mathrm{~mL})$ was added concentrated $\mathrm{HCl}(1.0 \mathrm{~mL})$ and the mixture maintained under reflux for 1 hour. After cooling to room temperature, $\mathrm{H}_{2} \mathrm{O}(10 \mathrm{~mL})$ was added, the reaction mixture was extracted with $\mathrm{CH}_{2} \mathrm{Cl}_{2}(3 \times 10 \mathrm{~mL})$ and the organic phases were combined and dried with $\mathrm{Na}_{2} \mathrm{SO}_{4}$. Concentration under reduced pressure gave the methylated crude product $(1.39 \mathrm{~g})$ which was then purified on a silica gel chromatographic column using hexane, hexane $/ \mathrm{CH}_{2} \mathrm{Cl}_{2} /$ hexane/AcOEt mixtures as eluents. The AGME fractions 24-28 (0.69g), AGME 29-30 (0.36g) and AGME 31-39 (0.19g) (AGME = methylated fatty acids), eluted with $8: 2$ hexane- $\mathrm{CH}_{2} \mathrm{Cl}_{2}, 1: 1$ hexane$\mathrm{CH}_{2} \mathrm{Cl}_{2}$ and 6: 4 hexane-ACOEt, respectively, in higher amounts and higher tlc purity were then subjected to GC / MS analysis.

\section{Results and discussion}

\section{Analysis of methylated derivatives $x$ identification of fatty acids}

The hexane fraction (FHEHXA) was subjected to saponification reaction $(\mathrm{KOH} / \mathrm{MeOH})$ to obtain the fatty acid salts (Saponification). These, after acidification, gave the free fatty acids which were then esterified, $(\mathrm{MeOH} / \mathrm{HCl})$ to yield the corresponding methyl esters (AGME). Silica gel column chromatography of the crude reaction product gave the fractions AGME 24-28, AGME 29-30 and AGME 31-39 (Methylation).

Analysis of AGME 24-28 in CG/MS showed the presence of ten fatty acids (Table 1 ), identified by the molecular ions. ${ }^{\mathrm{M}}+$ (consistent with the respective molecular formulas) corresponding to the respective methyl esters represented by the peaks with retention (RT) and percentages (\%) in the total ion chromatogram (Figure 1).

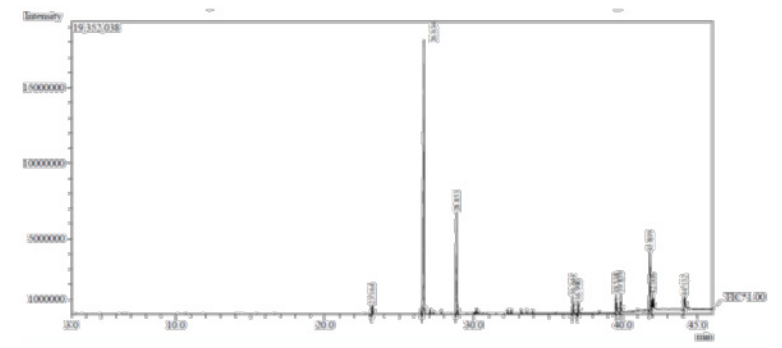

Figure I Chromatogram of AGME total ions 24-28

Mass spectra (MS) of the methylated components were also compared to mass spectra of fatty acid methyl esters reported in the literature and were consistent with the proposed structures, exhibiting characteristic $\mathrm{m} / \mathrm{z}$ ratio fragments, as described below. The main components were Z-octadec-9-enoic acid $(55.05 \%)$, octadeca-9-in11-trans-enoic acid (17.38\%) and Z-docos-13-enoic acids known as oleic acids, ximeninic and cis-19-octacosenoic acids, respectively

\begin{tabular}{|c|c|c|c|c|c|}
\hline Substance & Common name & $T_{R}(\min )$ & $\begin{array}{l}\text { Content } \\
(\%)\end{array}$ & M.M & F.M \\
\hline $\begin{array}{l}\text { Haxadecanoic } \\
\text { acid }\end{array}$ & Palmitic acid & 23,16 & $\mathrm{I}, 46$ & 256 & $\mathrm{C}_{16} \mathrm{H}_{32} \mathrm{O}_{2}$ \\
\hline $\begin{array}{l}\text { Cis-octadec-9- } \\
\text { enoic acid }\end{array}$ & Oleic acid & 26,63 & 55,05 & 282 & $\mathrm{C}_{18} \mathrm{H}_{34} \mathrm{O}_{2}$ \\
\hline $\begin{array}{l}\text { Octadeca-9-yn- } \\
\text { I I-trans-enoic } \\
\text { acid }\end{array}$ & ximeninic acid & 28,85 & 17,38 & 278 & $\mathrm{C}_{18} \mathrm{H}_{30} \mathrm{O}_{2}$ \\
\hline $\begin{array}{l}\text { Cis-tetracos-15- } \\
\text { enoic acid }\end{array}$ & Nervonic acid & 36,64 & 3,00 & 366 & $\mathrm{C}_{24} \mathrm{H}_{46} \mathrm{O}_{2}$ \\
\hline $\begin{array}{l}\text { Tetracosanoic } \\
\text { acid }\end{array}$ & Lignoceric acid & 36,99 & 2,05 & 368 & $\mathrm{C}_{24} \mathrm{H}_{48} \mathrm{O}_{2}$ \\
\hline $\begin{array}{l}\text { Cis-hexacos-17- } \\
\text { enoic acid }\end{array}$ & Ximenic acid & 39,54 & 3,06 & 394 & $\mathrm{C}_{26} \mathrm{H}_{50} \mathrm{O}_{2}$ \\
\hline $\begin{array}{l}\text { Hexacosanoic } \\
\text { acid }\end{array}$ & Ceric acid & 39,84 & 3,34 & 396 & $\mathrm{C}_{26} \mathrm{H}_{52} \mathrm{O}_{2}$ \\
\hline $\begin{array}{l}\text { Cis-octacos-19- } \\
\text { enoic acid }\end{array}$ & Acid Ximenixico ${ }^{a}$ & $4 I, 8 I$ & 9,85 & 422 & $\mathrm{C}_{28} \mathrm{H}_{54} \mathrm{O}_{2}$ \\
\hline $\begin{array}{l}\text { Octacosanoic } \\
\text { acid }\end{array}$ & Montanic acid & 42,01 & 2,28 & 424 & $\mathrm{C}_{28} \mathrm{H}_{52} \mathrm{O}_{2}$ \\
\hline $\begin{array}{l}\text { Trans-triacont- } \\
2 \text { I-enoic acid }\end{array}$ & Lumequeic acid & 44,13 & 2,22 & 450 & $\mathrm{C}_{30} \mathrm{H}_{58} \mathrm{O}_{2}$ \\
\hline
\end{tabular}
(Table 1).

Table I Fatty acids identified as methyl esters (AGME 24-28)

$\mathrm{T}_{\mathrm{R}}$, Retention time; M.M, Molar mass ( $\left.\mathrm{g} \mathrm{mol}^{-1}\right)$; F.M, Molecular formula.

A, common name used in this work.

The four saturated fatty acids (1, 5, 7 and 9) exhibited practically the same fragmentation pattern, with peaks due to breaks in the alkane chain $\left[\mathrm{M}-15\left(\mathrm{CH}_{3}\right)\right.$ to $\mathrm{M}-183\left(\mathrm{C}_{13} \mathrm{H}_{27}, 1\right), \mathrm{M}-295\left(\mathrm{C}_{21} \mathrm{H}_{43}, 5\right), \mathrm{M}-323$ $\left(\mathrm{C}_{23} \mathrm{H}_{47}, 7\right)$ and $\mathrm{M}-351\left(\mathrm{C}_{25} \mathrm{H}_{51}, 9\right)$, major peaks in $\mathrm{m} / \mathrm{z} 41,43,55,57$, 74,87 and 143 and base peak in $\mathrm{m} / \mathrm{z} 74$, the latter, resulting from Diels-Alder retro fragmentation. 
1. $\mathrm{T}_{\mathrm{R}}$ 23,164: $\mathrm{M}^{+} m / z 270$ (fórmula molecular $\mathrm{C}_{17} \mathrm{H}_{34} \mathrm{O}_{2}$ ), 239 [(M$31)^{+}$, perda de $\left.\mathrm{OCH}_{3}\right], 227(\mathrm{M}-43)^{+}, 213(\mathrm{M}-57)^{+}, 199(\mathrm{M}-71)^{+}, 185(\mathrm{M}-$ $85)^{+}, 171(\mathrm{M}-99)^{+}, 143\left(\mathrm{C}_{6} \mathrm{H}_{13} \mathrm{CO}_{2} \mathrm{CH}_{3}\right)^{+}, 101\left(\mathrm{CH}_{2} \mathrm{CH}_{2} \mathrm{CH}_{2} \mathrm{CO}_{2} \mathrm{CH}_{3}\right)^{+}$, $87\left(\mathrm{CH}_{2} \mathrm{CH}_{2} \mathrm{CO}_{2} \mathrm{CH}_{3}\right)^{+}, 74\left[\mathrm{H}_{2} \mathrm{C}=\mathrm{C}(\mathrm{OH}) \mathrm{OCH}_{3}\right]^{+*}, 55\left(\mathrm{H}_{2} \mathrm{CCH}=\mathrm{C}=\mathrm{O}\right)^{+}$, $57\left(\mathrm{C}_{4} \mathrm{H}_{9}\right)^{+}, 43\left(\mathrm{C}_{3} \mathrm{H}_{7}\right)^{+}$e $41\left(\mathrm{C}_{3} \mathrm{H}_{5}\right)^{+}$: Palmitic acid.

5. $\mathrm{T}_{\mathrm{R}}$ 36,990: $\mathrm{M}^{+} 382$ (fórmula molecular $\mathrm{C}_{25} \mathrm{H}_{50} \mathrm{O}_{2}$ ), 367 (M-15), 351 (M-31), 353 (M-29), 339 (M-43), 325 (M-57), 311 (M-71), 297 (M-85), 283 (M-99). Os picos principais foram em $m / z 41\left(\mathrm{C}_{3} \mathrm{H}_{5}\right)^{+}, 43$ $\left(\mathrm{C}_{3} \mathrm{H}_{7}\right)^{+}, 55\left(\mathrm{H}_{2} \mathrm{CCH}=\mathrm{C}=\mathrm{O}\right)^{+}, 57\left(\mathrm{C}_{4} \mathrm{H}_{9}\right)^{+}, 74\left(\mathrm{H}_{2} \mathrm{C}=\mathrm{C}(\mathrm{OH}) \mathrm{OCH}_{3}\right)^{+}, 87$ $\left(\mathrm{CH}_{2} \mathrm{CH}_{2} \mathrm{CO}_{2} \mathrm{CH}_{3}\right)^{+}$e $143\left(\mathrm{C}_{6} \mathrm{H}_{12} \mathrm{CO}_{2} \mathrm{CH}_{3}\right)^{+}$: Lignoceric Acid

.7. $\mathrm{T}_{\mathrm{R}}$ 39,538: $\mathrm{M}^{+} 410$ (fórmula molecular $\mathrm{C}_{27} \mathrm{H}_{54} \mathrm{O}_{2}$ ), 395 (M15), 381 (M-29), 367 (M-43), 353 (M-57), 339 (M-71), 325 (M85) e 311 (M-99). Os picos principais foram em $m / z 41\left(\mathrm{C}_{3} \mathrm{H}_{5}\right)^{+}, 43$ $\left(\mathrm{C}_{3} \mathrm{H}_{7}\right)^{+}, 55\left(\left(\mathrm{H}_{2} \mathrm{CCH}=\mathrm{C}=\mathrm{O}\right)^{+}, 57\left(\mathrm{C}_{4} \mathrm{H}_{9}\right)^{+}, 74\left(\mathrm{H}_{2} \mathrm{C}=\mathrm{C}(\mathrm{OH}) \mathrm{OCH}_{3}\right)^{+*}\right.$, $87\left(\mathrm{CH}_{2} \mathrm{CH}_{2} \mathrm{CO}_{2} \mathrm{CH}_{3}\right)^{+}$e $143\left(\mathrm{C}_{6} \mathrm{H}_{12} \mathrm{CO}_{2} \mathrm{CH}_{3}\right)^{+}$: Cerylic acid.

9. $\mathrm{T}_{\mathrm{R}}$ 42,006: $\mathrm{M}^{+} 438$ (fórmula molecular $\mathrm{C}_{29} \mathrm{H}_{58} \mathrm{O}_{2}$ ), 409 (M-29), 395 (M-43), 381 (M-57), 367 (M-71), 353 (M-85) e 339 (M-99) Os picos principais em $m / z 41\left(\mathrm{C}_{3} \mathrm{H}_{5}\right)^{+}, 43\left(\mathrm{C}_{3} \mathrm{H}_{7}\right)^{+}, 57\left(\mathrm{C}_{4} \mathrm{H}_{7}\right)^{+}, 55$ $\left(\mathrm{H}_{2} \mathrm{CCH}=\mathrm{C}=\mathrm{O}\right)^{+}, 74\left(\mathrm{H}_{2} \mathrm{C}=\mathrm{C}(\mathrm{OH}) \mathrm{OCH}_{3}\right)^{+*}, 87\left(\mathrm{CH}_{2} \mathrm{CH}_{2} \mathrm{CO}_{2} \mathrm{CH}_{3}\right)^{+} \mathrm{e}$ $143\left(\mathrm{C}_{6} \mathrm{H}_{12} \mathrm{CO}_{2} \mathrm{CH}_{3}\right)^{+}$; Mushroom Acid.

The five monounsaturated acids $(2,4,6,8$ and 10) exhibited the same pattern of fragmentation, with the principal peaks in $m / z 41,43$, $55,69,74,83,97,98$ and 111. It is worth highlighting in all these cases the peak due to the fragment in $\mathrm{M}-32(\mathrm{M}-\mathrm{CH} 3 \mathrm{OH})$, as well as the base peak in $m / z 55$.

2. $\mathrm{T}_{\mathrm{R}}$ 26,634, $\mathrm{M}^{+} 296$ (fórmula molecular $\mathrm{C}_{19} \mathrm{H}_{36} \mathrm{O}_{2}$ ), $m / z: 265$ (M-31), 264 (M-32), 222 (M-74), $111\left(\mathrm{CH}_{3} \mathrm{CH}_{2} \mathrm{CH}=\mathrm{CHCH}_{2} \mathrm{CH}_{2} \mathrm{CH}_{2} \mathrm{CH}_{2}\right)^{+}, 98$ $\left(\mathrm{CH}_{3} \mathrm{CH}_{2} \mathrm{CH}=\mathrm{CHCH}_{2} \mathrm{CH}_{2} \mathrm{CH}_{3}\right)^{+}, 97\left(\mathrm{CH}_{3} \mathrm{CH}_{2} \mathrm{CH}=\mathrm{CHCH}_{2} \mathrm{CH}_{2} \mathrm{CH}_{2}\right)^{+}$, $87 \quad\left(\mathrm{CH}_{2} \mathrm{CH}_{2} \mathrm{CO}_{2} \mathrm{CH}_{3}\right)^{+}, \quad 83 \quad\left(\mathrm{CH}_{2} \mathrm{CH}_{2} \mathrm{CH}_{2} \mathrm{CH}_{2} \mathrm{CH}^{2} \mathrm{CH}_{2}\right)^{+}$, $74\left(\left[\mathrm{H}_{2} \mathrm{C}=\mathrm{C}(\mathrm{OH}) \mathrm{OCH}_{3}\right]^{+}, \quad 69 \quad\left(\mathrm{CH}_{2} \mathrm{CH}_{2} \mathrm{CH}_{2} \mathrm{CH}=\mathrm{CH}_{2}\right)^{+}, \quad 55\right.$ $\left.\left[\left(\mathrm{CH}_{2} \mathrm{CH}_{2} \mathrm{CH}=\mathrm{CH}_{2}\right)^{+} \text {e/ou } \mathrm{H}_{2} \mathrm{C}=\mathrm{CH}-\mathrm{CO}\right)^{+}\right], \quad 43^{2}\left(\mathrm{C}_{3} \mathrm{H}_{7}\right)^{+}$e 41 $\left(\mathrm{CH}_{2} \mathrm{CH}=\mathrm{CH}_{2}\right)^{+}$; Oleic acid.

4. $\mathrm{T}_{\mathrm{R}} 36.644$, $\mathrm{M} 380$ (fórmula molecular $\mathrm{C}_{25} \mathrm{H}_{48} \mathrm{O}_{2}$ ), m/z: 349 (M-31), 348 (M-32), 306 (M-74), $111\left(\mathrm{CH}_{3} \mathrm{CH}_{2} \mathrm{CH}=\mathrm{CHCH}_{2} \mathrm{CH}_{2} \mathrm{CH}_{2} \mathrm{CH}_{2}\right)^{+}, 97$ $\left(\mathrm{CH}_{3} \mathrm{CH}_{2} \mathrm{CH}=\mathrm{CHCH}_{2} \mathrm{CH}_{2} \mathrm{CH}_{2}\right)^{+}, 83\left(\mathrm{CH}_{2} \mathrm{CH}_{2} \mathrm{CH}_{2} \mathrm{CH}_{2} \mathrm{CH}=\mathrm{CH}_{2}\right)^{+}, 74$ $\left(\left[\mathrm{H}_{2} \mathrm{C}=\mathrm{C}(\mathrm{OH}) \mathrm{OCH}_{3}\right]^{+}, 69\left(\mathrm{CH}_{2} \mathrm{CH}_{2} \mathrm{CH}_{2} \mathrm{CH}=\mathrm{CH}_{2}\right)^{+}, 57\left(\mathrm{C}_{4} \mathrm{H}_{9}\right)^{+}, 55\right.$ $\left.\left[\left(\mathrm{CH}_{2} \mathrm{CH}_{2} \mathrm{CH}=\mathrm{CH}_{2}\right)^{+} \text {e/ou } \mathrm{H}_{2} \mathrm{C}=\mathrm{CH}-\mathrm{CO}\right)^{+}\right], 43\left(\mathrm{C}_{3} \mathrm{H}_{7}\right)^{+}, 41\left(\mathrm{C}_{3} \mathrm{H}_{5}\right)^{+}$; Nervous Acid.

6. $\mathrm{T}_{\mathrm{R}} 39,538, \mathrm{M}^{+} 408$ (fórmula molecular $\mathrm{C}_{27} \mathrm{H}_{52} \mathrm{O}_{2}$ ), $\mathrm{m} / \mathrm{z}: 377$ (M31), $376(\mathrm{M}-32), 334(\mathrm{M}-74), 111\left(\mathrm{CH}_{3} \mathrm{CH}_{2} \mathrm{CH}=\mathrm{CHCH}_{2} \mathrm{CH}_{2} \mathrm{CH}_{2} \mathrm{CH}_{2}\right)^{+}$, $97\left(\mathrm{CH}_{3} \mathrm{CH}_{2} \mathrm{CH}=\mathrm{CHCH}_{2} \mathrm{CH}_{2} \mathrm{CH}_{2}\right)^{+}, 83\left(\mathrm{CH}_{2} \mathrm{CH}_{2} \mathrm{CH}_{2} \mathrm{CH}_{2} \mathrm{CH}=\mathrm{CH}_{2}\right)^{+}$, $74\left(\left[\mathrm{H}_{2} \mathrm{C}=\mathrm{C}^{2}(\mathrm{OH}) \mathrm{OCH}_{3}\right]^{+}, 69^{2}\left(\mathrm{CH}_{2} \mathrm{CH}_{2} \mathrm{CH}_{2} \mathrm{CH}=\mathrm{CH}_{2}\right)^{+}, 57^{2}\left(\mathrm{C}_{4} \mathrm{H}_{9}\right)^{+}, 55\right.$ $\left.\left[\left(\mathrm{CH}_{2} \mathrm{CH}_{2} \mathrm{CH}=\mathrm{CH}_{2}\right)^{+} \text {e/ou } \mathrm{H}_{2} \mathrm{C}=\mathrm{CH}-\mathrm{CO}\right)^{+}\right], 43\left(\mathrm{C}_{3} \mathrm{H}_{7}\right)^{+}, 41\left(\mathrm{C}_{3} \mathrm{H}_{5}\right)^{+}$; Ximenic Acid.

8. $\mathrm{T}_{\mathrm{R}} 41,809, \mathrm{M}^{+} 436$ (fórmula molecular $\mathrm{C}_{29} \mathrm{H}_{56} \mathrm{O}_{2}$ ), $\mathrm{m} / \mathrm{z}$ : 405 (M31), $404(\mathrm{M}-32), 362(\mathrm{M}-74), 111\left(\mathrm{CH}_{3} \mathrm{CH}_{2} \mathrm{CH}=\mathrm{CHCH}_{2} \mathrm{CH}_{2} \mathrm{CH}_{2} \mathrm{CH}_{2}\right)^{+}$, $97\left(\mathrm{CH}_{3} \mathrm{CH}_{2} \mathrm{CH}=\mathrm{CHCH}_{2} \mathrm{CH}_{2} \mathrm{CH}_{2}\right)^{+}, 83\left(\mathrm{CH}_{2} \mathrm{CH}_{2} \mathrm{CH}_{2} \mathrm{CH}_{2} \mathrm{CH}=\mathrm{CH}_{2}\right)^{+}$, $74\left(\left[\mathrm{H}_{2} \mathrm{C}=\mathrm{C}(\mathrm{OH}) \mathrm{OCH}_{3}\right]^{+}, 69\left(\mathrm{CH}_{2} \mathrm{CH}_{2} \mathrm{CH}_{2} \mathrm{CH}=\mathrm{CH}_{2}\right)^{+}, 57\left(\mathrm{C}_{4} \mathrm{H}_{9}\right)^{+}, 55\right.$ $\left.\left[\left(\mathrm{CH}_{2} \mathrm{CH}_{2} \mathrm{CH}=\mathrm{CH}_{2}\right)^{+} \text {e/ou } \mathrm{H}_{2} \mathrm{C}=\mathrm{CH}-\mathrm{CO}\right)^{+}\right], 43\left(\mathrm{C}_{3} \mathrm{H}_{7}\right)^{+}, 41\left(\mathrm{C}_{3} \mathrm{H}_{5}\right)^{+}$; Ximenoic acid (cis-19-octacosenoic acid).

10. $\mathrm{T}_{\mathrm{R}} 44,132, \mathrm{M}^{+} 464$ (fórmula molecular $\mathrm{C}_{31} \mathrm{H}_{60} \mathrm{O}_{2}$ ), $m / z: 433$ (M31), 432 (M-32), 390 (M-74), $111\left(\mathrm{CH}_{3} \mathrm{CH}_{2} \mathrm{CH}=\mathrm{CHCH}_{2} \mathrm{CH}_{2} \mathrm{CH}_{2} \mathrm{CH}_{2}\right)^{+}$, $97\left(\mathrm{CH}_{3} \mathrm{CH}_{2} \mathrm{CH}=\mathrm{CHCH}_{2} \mathrm{CH}_{2} \mathrm{CH}_{2}\right)^{+}, 83\left(\mathrm{CH}_{2} \mathrm{CH}_{2} \mathrm{CH}_{2} \mathrm{CH}_{2} \mathrm{CH}=\mathrm{CH}_{2}\right)^{+}$, $74\left(\left[\mathrm{H}_{2} \mathrm{C}=\mathrm{C}(\mathrm{OH}) \mathrm{OCH}_{3}\right]^{+}, 69\left(\mathrm{CH}_{2} \mathrm{CH}_{2} \mathrm{CH}_{2} \mathrm{CH}^{2} \mathrm{CH}_{2}\right)^{+}, 57\left(\mathrm{C}_{4} \mathrm{H}_{9}\right)^{+}\right.$, $\left.55\left[\left(\mathrm{CH}_{2} \mathrm{CH}_{2} \mathrm{CH}=\mathrm{CH}_{2}\right)^{+} \text {e/ou } \mathrm{H}_{2} \mathrm{C}=\mathrm{CH}-\mathrm{CO}\right)^{+}\right], \quad 43 \quad\left(\mathrm{C}_{3} \mathrm{H}_{7}\right)^{+}, 41$ $\left(\mathrm{C}_{3} \mathrm{H}_{5}\right)^{+} ;$Lumequeic Acid.

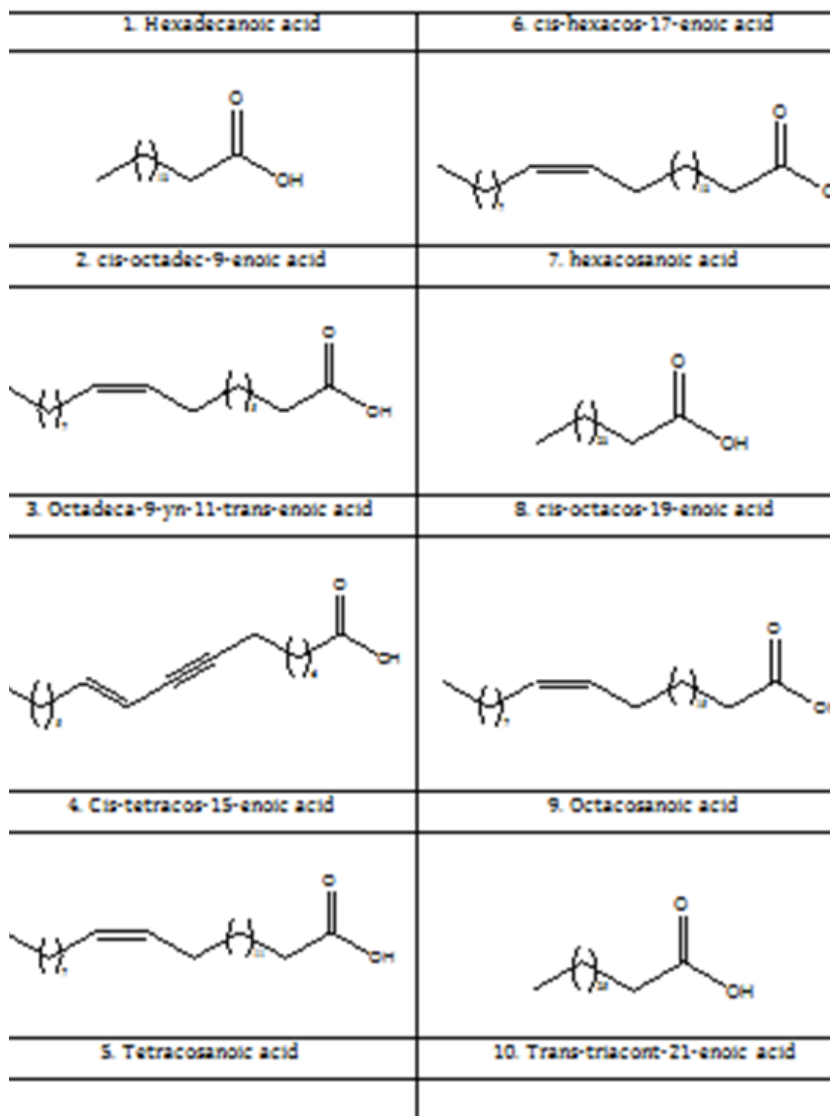

Figure 2 Structures of fatty acids identified in grains of $X$. americana.

In the case of the component with retention time 28,853 (3) a distinct fragmentation pattern was observed. Except for the peaks in $m / z 41$ and 43, fragments common to all and the peak in $m / z 55$, observed in the unsaturated acid spectra 2, 4, 6, 8 and 10, the mass spectrum of 3 showed the peaks $m / z 67,79,80,93$ and 150, with the base peak in $m / z 79$. The highlights were the peaks due to fragments in $m / z 261\left(\mathrm{M}-31\right.$ loss of $\left.\left.\mathrm{OCH}_{3}\right), 219-\mathrm{CH}_{2} \mathrm{CH}_{2} \mathrm{CH}=\mathrm{CH}\left(\mathrm{CH}_{2}\right) 5 \mathrm{CH}_{3}\right]$ $+\mathrm{en} / \mathrm{z} 150\left[\mathrm{H}_{2} \mathrm{C}=\mathrm{CHCH}=\mathrm{CH}\left(\mathrm{CH}_{2}\right) 5 \mathrm{CH}_{3}\right]$., both indicative of a $\mathrm{C}_{18}$-enine structure with the triple bond between $\mathrm{C}_{9}$ and $\mathrm{C}_{10}$ carbons. ${ }^{10,11}$ The base peak in $m / z 79\left(\mathrm{C}_{6} \mathrm{H}_{7}\right)+$ indicated the presence of more than one double or triple bond in the fatty acid chain. ${ }^{12}$

3. $28,853, \mathrm{M}^{+} 292$ (fórmula molecular $\mathrm{C}_{19} \mathrm{H}_{32} \mathrm{O}_{2}$ ), $\mathrm{m} / \mathrm{z}: 261$ (M31), 219 (M-73), 164, 150, $135\left(\left[\mathrm{H}_{2} \mathrm{C}=\mathrm{C}=\mathrm{CHCH}=\mathrm{CH}\left(\mathrm{CH}_{2}\right)_{5}\right]^{+}, 121\right.$ $\left[\left[\mathrm{H}_{2} \mathrm{C}=\mathrm{C}=\mathrm{CHCH}=\mathrm{CH}\left(\mathrm{CH}_{2}\right)_{4}\right]^{+}, \quad 107 \quad\left[\mathrm{H}_{2} \mathrm{C}=\mathrm{C}=\mathrm{CHCH}=\mathrm{CH}\left(\mathrm{CH}_{2}\right)_{3}\right]^{+}\right.$, $93\left[\mathrm{H}_{2} \mathrm{C}=\mathrm{C}=\mathrm{CHCH}=\mathrm{CH}\left(\mathrm{CH}_{2}\right)_{2}\right]^{+}, 79\left[\mathrm{H}_{2} \mathrm{C}=\mathrm{C}=\mathrm{CHCH}=\mathrm{CHCH}_{2}\right]^{+}, 67$ $\left[\mathrm{HCC}\left(\mathrm{CH}_{2}\right)_{3}\right]^{+}, 55\left(\mathrm{C}_{3} \mathrm{H}_{3} \mathrm{O} / \mathrm{C}_{4} \mathrm{H}_{7}\right)^{+}, 43\left(\mathrm{C}_{3} \mathrm{H}_{7}\right)^{+}$e $41\left(\mathrm{C}_{3} \mathrm{H}_{5}\right)^{+}$; Ximeminic Acid.

The structures of the fatty acids identified in the grains of $X$. americana are shown in Figure 2. The fractions AGME 29-30 and AGME 32-39 (Methylation), By GC/MS analysis, practically led to the same constituents of the AGME fraction 24-28.

\section{Conclusion}

Analysis of the oil of $X$. americana seeds by gas chromatography coupled to mass spectrometry using the saponification/methylation route allowed the identification of ten fatty acids. Four of these acids (palmitic, oleic, ximeninic and lignoceric) had already been identified 
by analyzing the oil of these seeds via derivatization by silylation, also by gas chromatography coupled to mass spectrometry. It was possible to identify other six fatty acids (ceric, nerve, montane, ximenic, oxymic and lumeochemical), as well as to confirm the presence of the first four, contributing significantly to the knowledge of the composition of the oil of the species under study. It is worth mentioning the high content $(19.77 \%)$ of total proteins and the high percentage (about 27.71\%) of oil in the seeds of the edible fruits of this plant species, which, together with its spread in Northeast Brazil, possible use as a nutraceutical, in cosmetology or even for the production of alkyl fatty acid monoesters (biodiesel). In addition, the present study contributed to increase knowledge about the medicinal potential of $X$. americana. Cataplasms of plants of the genus Ximênia are used as masks for treatment of the skin. The ximeninic acid and its ethyl ester (ximenoil) have topical action, being used in the form of emulsions with anti-cellulite action.

\section{Acknowledgments}

The authors thank the funding agencies (CAPES, CNPq and FUNCAP) for funding this work and for supporting the Postgraduate Program in Chemistry of the Federal University of Ceará. Special thanks to the Foundation for Research Support of the State of Piaui (FAPEPI)

\section{Conflicts of interest}

The authors declare no conflicts of interest.

\section{References}

1. mariafernadaelias.com.br

2. Vianni R, Braz-Filho R. Ácidos Graxos Naturais:importancia e ocorrência em Alimentos. Química Nova. 1996;19(4):400-407.
3. Silva RAC, Lemos TLG, Ferreira DA, et al.Ximenia Americana:Chemical and Spectral Studies of Extracts of Seeds. Analysis of Thrimethylsilyl Derivatives by Gas Chromatography and Mass Spectrometry. Chemistry \& Material Science. 2016; 7:(2):192-202

4. Kates M. Techniques of lipidology in Laboratory Techniques in Bichemistry and Molecular Biology. In: Burdon H, van Knippenberg PH, editors. Elsevier, Amsterdam, 1986. pp. 100-110.

5. Monte FJQ, Lemos TLG, Araújo MRS, et al. Phytochemiclas, a global perspective of their role in nutrition and health. Agricultural and Biological Sciences. 2012. pp. 429-450.

6. Bombardelli E, Guglielmini G, Morazzoni P, et al. Microvasculokinetic activiy of ximenynic aci and ethyl ester. Fitoterapim. 1994 ;3:195-201.

7. Cristoni A, Guglielmini G, Stucchi P, et al. A unsaturated fatty acid from traditional African cosmesis. Proceedings in Cosmetics, New York, USA. 1999.

8. Yand D Liu, Robert B Longmore, et al. Separation and Identification of Ximenynic Acid Isomers in the Seeds of Santalium spicatum Br. As Their 4,4-Dimethyloxazoline Derivatives. Journal of the American Oil Chemists'Society. 1996;73(12):1729-1731.

9. Nogueira ARA, Souza GB. Manual de Laboratórios:Solo, Água, Nutrição Vegetal, Nutrição Animal e Alimentos. Embrapa Pecuária Sudeste, São Carlos, Brazil. 2005.

10. Spitzer V, Marx F, Maia JGS, et al. Curupira tefeensis Occurrence of Acetylenic Fatty Acids. Fat Sci Technol. 1991;93(5):169-174.

11. Kleiman R, Bohannon MB, Gunstone FD, et al. Mass Spectra of Acetylenic Fatty Acid Methyl Esters Derivatives. Lipids. 1976;11:599603

12. Murphy RC. Handbook of Lipid Research 7:Mass Spectrometry of Lipids. Plenum, New York, USA, 1993. pp. 71-130. 